\title{
Complete correction of transposition of the great arteries with left juxtaposition of the atrial appendages
}

\author{
BER NARDOA. VIDNE ${ }^{1}$ and S. SUBRAMANIAN \\ Department of Cardiovascular Surgery, Children's Hospital, Buffalo, New York, USA
}

\begin{abstract}
Vidne, B. A. and Subramanian, S. (1976). Thorax, 31, 178-180. Complete correction of transposition of the great arteries with left juxtaposition of the atrial appendages. Juxtaposition of the atrial appendages is an uncommon anomaly which is usually associated with transposition of the great arteries. Experience with five patients with transposition of the great arteries in combination with juxtaposition of the atrial appendages in whom Mustard's operation was performed is reviewed. Technically, the existence of juxtaposition of the atrial appendages in corrective surgery for transposition does not present any additional surgical problems. Emphasis is placed on the advantages of early complete correction, avoiding the need for palliative procedure.
\end{abstract}

Juxtaposition of the atrial appendages refers to that condition in which both atrial appendages, or one and part of the other, lie beside each other and to one side of the great arteries. The appendage lying to the left of the great arteries is called left-sided juxtaposition and is considerably more common by a ratio of about $6: 1$ than the situation in which the appendages lie to the right of the great arteries-right-sided juxtaposition. Among left-sided juxtapositions, Charuzi et al. (1973) described a partial juxtaposition state when the right atrial appendage is bifid and only its left unit is juxtaposed.

Juxtaposition of the atrial appendages is nearly always associated with significant congenital heart disease in which transposition of the great arteries is commonly a feature. Tricuspid atresia, double outlet ventricle or double inlet ventricle have also been described (Dixon, 1954; Puech et al., 1966; Melhuish and VanPraagh, 1968; Santoli et al., 1968; Wagner, Alday, and Vlad, 1970; Charuzi et al., 1973).

Between 1971 and 1974, five patients with transposition of the great arteries and juxtaposition of the atrial appendages underwent Mustard's operation and are the basis of this report.

\section{PATIENTS}

From a total of 116 Mustard operations for transposition of the great arteries, including transposi-

Present address: Thoracic and Cardiovascular Department, Beilinson Medical Center, Medical School, Tel-Aviv University, Israel tion with intact ventricular septum and normal pulmonary artery pressure, intact ventricular septal defect (VSD) and pulmonary artery hypertension, complicated transposition with ventricular septal defect and pulmonic and subpulmonic stenosis, five patients had, in addition, juxtaposition of the right atrial appendages. In only one of them was combined juxtaposition of the atrial appendages suspected preoperatively owing to the catheter position. All five patients had left juxtaposition of the atrial appendages.

The ages of these five patients ranged from 33 months to 10 years, being less than 18 months in $\delta$ three of the five (Table I).

All the patients presented with complicated $ᄋ$ transposition. Complicating lesions consisted of $D$ subpulmonic VSD in all patients, subpulmonic stenosis in three patients presenting with a sub- $\bar{N}$ pulmonary conus (pulmonary-mitral valve discon- $\Omega$ tinuity), pulmonic valvular stenosis in one, patent $\tilde{O}$ ductus arteriosus in two patients, and a left $\underset{\omega}{N}$ superior vena cava draining to the coronary sinus in one patient.

In three of the five patients, a previous palliative $\overparen{\mathscr{D}}$ operation had been done elsewhere, consisting of $\stackrel{\mathcal{C}}{+}$ pulmonary artery banding in the three and an $\frac{T}{T}$ additional Blalock-Taussig anastomosis in one. $\frac{O}{\mathbb{D}}$

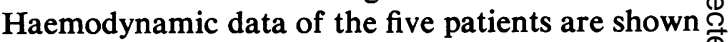

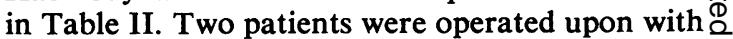
standard cardiopulmonary extracorporeal circula- $\overline{-}$ tion. Three of the five were operated upon under 8 
T A B L E I

CLINICAL DATA IN FIVE PATIENTS WITH LEFT JUXTAPOSITION OF THE RIGHT ATRIAL APPENDAGE WHO UNDERWENT MUSTARD'S PROCEDURE

\begin{tabular}{|c|c|c|c|c|c|c|c|c|c|}
\hline Age & Weight (kg) & CHF & Cyanosis & Tachypnoea & Hepatomegaly & ECG & Cardiomegaly & $\underset{(\mathrm{g} / \mathrm{dl})}{\mathrm{Hb}}$ & $\begin{array}{l}\text { Previous Palliative } \\
\text { Procedure }\end{array}$ \\
\hline $15 \mathrm{~m}$ & $7 \cdot 6$ & + & + & + & + & \multirow{2}{*}{$\begin{array}{l}\text { LVH } \\
\text { RVH } \\
\text { LVH } \\
\text { RVH }\end{array}$} & + & $17 \cdot 3$ & \multirow{3}{*}{$\begin{array}{l}\text { Pulmonary artery } \\
\text { banding } \\
\text { Rashkind septostomy, } \\
\text { pulmonary artery } \\
\text { banding }\end{array}$} \\
\hline $18 \mathrm{~m}$ & $9 \cdot 3$ & + & + & + & + & & + & $16 \cdot 4$ & \\
\hline $4 \frac{1}{2} y^{1}$ & & \pm & + & - & \pm & \multirow{2}{*}{$\begin{array}{l}\text { LVH } \\
\text { RVH } \\
\text { RV } \\
\text { RVH }\end{array}$} & \pm & $13 \cdot 7$ & \\
\hline $\begin{array}{l}3 \mathrm{~m} \\
10 \mathrm{yr}\end{array}$ & $\begin{array}{r}4 \cdot 7 \\
19 \cdot 1\end{array}$ & + & + & + & $\bar{t}$ & & \pm & $\begin{array}{l}14 \cdot 0 \\
15 \cdot 4\end{array}$ & $\begin{array}{l}\text { Rashkind septostomy } \\
\text { Pulmonary artery } \\
\text { banding, } \\
\text { Blalock-Taussig shunt }\end{array}$ \\
\hline
\end{tabular}

'Goldenhar's syndrome (Goldenhar, 1952).

T A B L E I I

HAEMODYNAMIC DATA IN FIVE PATIENTS WITH LEFT JUXTAPOSITION OF THE RIGHT ATRIAL APPENDAGE WHO UNDERWENT MUSTARD'S PROCEDURE

\begin{tabular}{|c|c|c|c|c|c|c|c|c|c|c|c|c|c|c|}
\hline \multicolumn{6}{|c|}{ Pressure (mmHg) } & \multicolumn{9}{|c|}{ Oxygen Saturation \% } \\
\hline $\mathbf{R A}$ & LA & $\mathbf{R V}$ & PA & $\mathbf{L V}$ & Ao & SVC & ICV & $\mathbf{R A}$ & $\mathbf{R V}$ & PA & PV & LA & LV & Ao \\
\hline $\begin{array}{l}6 \\
3 \\
5 \\
6 \\
3\end{array}$ & $\begin{array}{l}\overline{-} \\
\overline{5} \\
5 \\
3\end{array}$ & $\begin{array}{l}90 / 10 \\
62 / 5 \\
95 / 5 \\
70 / 5 \\
100 / 12\end{array}$ & $\begin{array}{l}133 / 15 \\
35 / 20 \\
40 / 25 \\
16 / 10 \\
16 / 12\end{array}$ & $\begin{array}{l}115 / 10 \\
70 / 7 \\
100 / 6 \\
78 / 6 \\
105 / 10\end{array}$ & $\begin{array}{l}90 / 45 \\
90 / \\
95 / 60 \\
70 / 40 \\
100 / 50\end{array}$ & $\begin{array}{l}36 \\
60 \\
38 \\
60\end{array}$ & $\frac{\overline{-}}{\frac{60}{57}}$ & $\begin{array}{l}45 \\
66 \\
44 \\
57\end{array}$ & $\begin{array}{l}52 \\
69 \\
49 \\
71\end{array}$ & $\begin{array}{l}- \\
\overline{83} \\
69 \\
83\end{array}$ & $\begin{array}{r}97 \\
87 \\
100 \\
95\end{array}$ & $\begin{array}{l}\frac{62}{77} \\
85 \\
75\end{array}$ & $\begin{array}{l}59 \\
87 \\
89 \\
89\end{array}$ & $\begin{array}{l}57 \\
74 \\
79 \\
67 \\
77\end{array}$ \\
\hline
\end{tabular}

surface-induced deep hypothermia, limited cardiopulmonary bypass, and circulatory arrest as described elsewhere (Subramanian and Wagner, 1973).

Total cardiocirculatory arrest was achieved at $20^{\circ} \mathrm{C}$ after cross-clamping the aorta and the superior and inferior venae cavae. The ductus arteriosus, when present, was ligated before circulatory arrest. A transverse incision was made in the right atrium and the atrial septum was completely excised, taking care to leave a wide rim anteriorly to preserve the middle internodal tract. The coronary sinus was cut in two of the five patients. The prepared pericardial patch was inserted into the atrial cavity so as to redirect the pulmonary blood into the right ventricle and the cava and the coronary sinus blood into the left ventricle. Both appendages were left connected to the left atrial cavity, thereby enlarging it. In four patients, VSD closure was performed through the tricuspid valve without detaching the valve. In the youngest patient, 3 months old, the subpulmonic conus was found to be very tightly stenosed and a satisfactory outflow was not obtained. A pericardial tube was used as an outflow conduit from the right ventricle to the distal transsected main pulmonary artery. Circulatory arrest time averaged 35 minutes.

In two patients, the right atrial cavity was enlarged using a pericardial patch in one and Dacron in the other (Table III).

T A B L E I I I

SURGICAL DATA IN FIVE PATIENTS WITH LEFT JUXTAPOSITION OF THE RIGHT ATRIAL APPENDAGE WHO UNDERWENT MUSTARD'S PROCEDURE

\begin{tabular}{|c|c|c|c|c|c|c|c|c|c|c|}
\hline \multirow[b]{2}{*}{$\underset{\text { Hypothermia }}{\text { Deep }}$} & \multirow[b]{2}{*}{ Baffle Patch } & \multicolumn{8}{|c|}{ Associated Procedures } & \multirow[b]{2}{*}{ Result } \\
\hline & & VSD & PS & PDA & Debanding & $\begin{array}{l}\text { Closure } \\
\text { Shunt }\end{array}$ & $\begin{array}{c}\text { PA } \\
\text { Reconstruction }\end{array}$ & $\begin{array}{l}\text { Coronary } \\
\text { Sinus }\end{array}$ & $\begin{array}{l}\text { Pulmonary } \\
\text { Mitral } \\
\text { Continuity }\end{array}$ & \\
\hline+ & Pericardium & + & + & + & + & & + & Cut & + & Good \\
\hline$\frac{+}{ \pm}$ & $\begin{array}{l}\text { Pericardium } \\
\text { Pericardium } \\
\text { Pericardium } \\
\text { Pericardium }\end{array}$ & $\begin{array}{l}+ \\
+ \\
+ \\
+\end{array}$ & $\frac{\bar{t}}{+}$ & $\frac{\bar{t}}{+}$ & $\frac{+}{+}$ & + & + & Cut & $\begin{array}{l}+ \\
\pm \\
-\end{array}$ & $\begin{array}{l}\text { Good } \\
\text { Died } \\
\text { Died } \\
\text { Good }\end{array}$ \\
\hline
\end{tabular}




\section{RESULTS}

Two of the five patients died immediately after surgery. One, 3 months old, died because of low cardiac output four hours after surgery. No obvious cause for the low output state was found. The second death was in a $4 \frac{1}{2}$-year-old child who died immediately after surgery due to low cardiac output. At necropsy moderate to severe pulmonary vascular disease was found.

In all three surviving patients, tracheostomy was performed. One developed a complete A-V block and a permanent pacemaker was implanted.

The follow-up period is from six months to four years. There were no late deaths and no evidence of pulmonary venous obstruction.

Technically, correction of transposition of the great arteries in patients with additional juxtaposition of the atrial appendages does not present any great problem, especially with the use of deep hypothermia and circulatory arrest.

\section{DISCUSSION}

From a functional point of view, juxtaposition of the atrial appendages appears to be of no significance although it may give rise to a confusing situation in diagnostic studies. In patients with transposition of the great arteries and juxtaposition of the atrial appendage, the abnormally placed atrial appendage could be particularly relevant in some palliative procedures. In performing balloon septostomy, the catheter may appear to conform to the criteria of a left atrial position and still be in the right atrial appendages in left-sided juxtaposition (Tyrrell and Moes, 1971; Rosenquist, Stark, and Taylor, 1974).

A Blalock-Hanlon atrial septectomy could be more difficult to perform since the part of the right atrium between the interatrial groove and the atrioventricular groove is smaller. In this case, the inflow occlusion technique would be more appropriate. Technically, the presence of juxtaposition of the atrial appendage in the correction of transposition of the great arteries does not present any additional surgical problem. All the patients presented had left juxtaposition of the right atrial appendage which appeared combined with 'correctable complicated transposition of the great arteries' in contrast to the right juxtaposition which appears to be combined with 'non-correctable lesions'.

As a result of our surgical experience and the potential difficulties in performing classical palliative procedures, in this particular group of patients with these combined anomalies early correction is strongly recommended.

\section{REFERENCES}

Charuzi, Y., Spanos, P. K., Amplatz, K., and Edwards, J. E. (1973). Juxtaposition of the atrial appendages. Circulation, 47, 62.

Dixon, A. S. J. (1954). Juxtaposition of the atrial to appendages: two cases of an unusual congenital cardiac deformity. British Heart Journal, 16, 153. $\infty$

Goldenhar, M. (1952). Associations malformatives de 윽 l'oeil et de l'oreille, en particulier le syndrome et $\rightarrow$ dermoïde epibulbaire-appendices auriculaires- $D$ fistula auris congenita et ses relations avec la dysostose mandibulo-faciale. Journal de Génétique Humaine, 1, 243.

Melhuish, B. P. P. and VanPraagh, R. V. (1968). बे Juxtaposition of the atrial appendages: a sign of severe cyanotic congenital heart disease. British Heart Journal, 30, 269.

Puech, P., Latour, H., Hertault, J., Grolleau, R., and Robert M. (1966). La juxtaposition des auricules: a propos de trois observations. Archives des $\stackrel{\mathbb{D}}{\mathbb{D}}$ Maladies du Coeur et des Vaisseau, 59, 239.

Rosenquist, G. C., Stark, J., and Taylor, J. F. N. (1974). Anatomical relationships in transposition of the great arteries: juxtaposition of the atrial appendages. Annals of Thoracic Surgery, 18, 456.

Santoli, C., Pellegrini, A., Mezzacapo, B., and Distante, S. (1968). La giustapposizione auricolare. Atti della Societa Italiana di Cardiologia, 2, 8.

Subramanian, S. and Wagner, H. (1973). Correction $\dot{0}$ of transposition of the great arteries in infants 3 under surface induced deep hypothermia. Annals $\dot{\varnothing}$ of Thoracic Surgery, 16, 391.

Tyrrell, M. J. and Moes, C. A. F. (1971). Congenital levoposition of the right atrial appendage: its relevance to balloon septostomy. American $D$ Journal of Diseases of Children, 121, 508.

Wagner, H. R., Alday, L. E., and Vlad, P. (1970). N Juxtaposition of the atrial appendages: a report $\sigma$ of six necropsied cases. Circulation, 42, 157.

Requests for reprints to: Professor S. Subramanian, FRCS, Department of Cardiovascular Surgery, Child- $e$ ren's Hospital, 219 Bryant Street, Buffalo, New York State, USA. 